\title{
Adatok Bagol András történelem szemléletéhez
}

\author{
PERGER GYULA \\ Kuny Domokos Múzeum, H-2892 Tata, Pf. 224., e-mail: pergergyula61@gmail.com
}

Perger, Gy.: On András Bagol's View of History.

Abstract: András Bagol's ouvre caught the attention of the ethnographers already in the early 20th century. His sheperd's crooks, which were inlaid with wax and embellished with historical scenes or portraits of Hungarian heroes, were sought after among the wealthy collectors and public collections alike. They are pieces of art of the highest quality, in which the sheperds' tradition of the Transdanubia is preserved. One of his works, which has been previously unknown, is kept in the museum of Györ: a sheperd's crook with wax inlay from the year of 1877. This crook was made in honor of Kázmér Hegedüs, its central themes are, beside the customer's family, the herds of horses on the Great Hungarian Plains and the city of Pécs. Some previously unknown letters of Bagol written to Ottó Herman verify that he was a soldier in 184849 and was forced into hiding after the fall of the War of Independence. From the 1880 s he resumed an active role in politics as a canvasser of the 48 Independence Party (48-as Függetlenségi Párt). One of his poems he wrote about the elections reveals his view of history, elements of which are indicated in the carvings of his many crooks as well.

Keywords: sheperd art, view of history, Ottó Herman

Mándoki László 1978-ban, a Somogyi Múzeumok Közleményeinek hasábjain, Bagol András Pécsett örzött faragványainak ismertetése kapcsán vetette fel, hogy reményei szerint, írása „... nyomán más múzeumok is közreadják a tulajdonukban levő Bagol András faragványokat. Ezáltal közkinccsé válhat e méltatlanul elfeledett alkotó(k) máig fennmaradt oeuvre-je."1 A „felhívás"-t követően Győrffy István szemészprofesszor az Ethnographia XCIV. évfolyamában „Adatok Bagol András botfaragó munkásságához" címen - képekkel és rajzokkal illusztrálva - tette közzé pásztormüvészeti gyüjteményének négy, Bagol András által készített darabját. ${ }^{2}$ 1987-ben - szintén az Ethnographiaban S. Kovács Ilona, a Néprajzi Múzeum pásztormüvészeti gyűjteményének vezetője foglalta össze - akkor újszerü megközelítéssel - „Bagol András faragópásztor” munkásságát. Ugyanebben az évben az Élet és Tudomány rövid - de annál tartalmasabb cikket közölt Szelestey László tollából, „Ki volt Bagol András?”címmel. ${ }^{3}$

Az ezredfordulón, a Somogy megye népmüvészetét bemutató reprezentatív kötetbe a pásztorművészettel - $\mathrm{s}$ benne Bagol-lal - már korábban is foglalkozó Kovács llona összegezte mindazt, amit a jeles „faragópásztorról" s munkáiról tudni lehetett. Müveit a pásztor-

Mándoki L. 1978: 270.

2 Györffy I. 1983: 423-431.

3 Szelestey L. 1987: 1548-1549. E cikk változata újabb illusztrációkkal megjelent. Szelestey L. 2001: 26-27. müvészet „Virágkor”-ának darabjaiként tartja számon, amikor „a kilencvenes években kiadott és a parasztság körében is terjedő hazafias... kiadványok hatására, a történelmi személyek és események ábrázolására is egyre több példát találunk.” "Bagol András botfaragó volt. Kivadáron és a Baranya megyei Botykán szolgált pásztorként. Csak kései faragványait ismerjük, melyeket 1891 és 1903 között faragott. Sorozatban készitette a vékony botokat, fokosokat és karikásnyelet. Használatra alkalmas szerszámot alig ismerünk töle. A faragványainak a szerkezete és mérete eltérö, viszont a formája, a technikák: karcolás, domborúfaragás, ónöntés, színezés; a motívumok egy része és a díszitmény felépitése beleillik a hagyományba.

Faragványait történelmi képekkel dísziti, amihez feltehetően a korabeli kiadványok illusztrációit használja elöképként. Átfogalmazza a sajátos pásztormüvészeti formanyelvre, vagyis a jelenetböl kiemel egykét személyt és a hozzájuk tartozó jelképes tárgyat, amit felnagyit. A pásztor és betyárfigurákhoz hasonlóan a történelmi személyiségeket is egy-egy jelképes motívummal és a jellegzetes öltözékkel jellemez. Kossuth Lajos mentés, szakállas figura, fején Kossuth kalap, a kezében zászlót tart, Petöfi a Nemzeti dalt tartalmazó irattekercset fogja, Batthyány Lajos mellé szomorúfüzet farag, Lehel vezér kürtöt tart a kezében. A motívumokat megnevezi, például a szirén felirata: „ÉN HABLEÁNY VAGYOK JAJ NEKTEK MAGYAROK." Bagol legtöbb faragványa ajándék, ezért írja rájuk a magyarázó feliratokat."

Bagol munkássága már a XX. század eleje óta ismert (és elismert) volt, vagy lehetett az érdeklődő nagyközönség előtt. Malonyay Dezső munkájából ${ }^{6} \mathrm{az}$ életrajzi adatokon kívül - dunántúli arisztokrata családok birtokain cseléd, juhász, majd öreg korában csősz - az is kiderül, hogy Bagol munkái keresett darabok lehettek a századfordulón. Nemcsak munkaadóinak készített "névre szóló" botokat, ezek tovább is ajándékozták azokat. Malonyay A magyar Nép Müvészete III. kötetének végén - annak ellenére, hogy csupán egy munkájának rajzát adja ${ }^{7}$ - önálló fejezetet szentelt a "müvész" Bagol Andrásnak. ${ }^{8} \mathrm{Az}$ egyébként is anekdotisztikus életképpel indított írásban Malonyay olyan legendát teremtett, amely szinte egy évszáza-

\footnotetext{
4 S. Kovács I. 2001: 356.

5 S. Kovács I. 2001: 369 .

6 Malonyay D. 1911:

7 Malonyay D. 1911: 111.

8 Malonyay D. 1911: 293-298.
} 
dig meghatározta a Bagol Andrásról kialakított képet. Az Atlanti Óceán partján Heywood az „amerikai képfaragó”, Somssich „a magyar gróf, aki egész komolyan müvész akar lenni s úgy él, úgy tanul, úgy dolgozik, mintha semmi köze se volna ahhoz a somogyi dominiumhoz, amely egykor az övé lesz bizonyosan, [...] Cambell, a skót festő és Pixotto, a spanyol piktor" és Malonyay az eső elől a teraszra húzódva a művész és müvészet mibenléte felett merengenek. „És ott volt vélünk Alexandre Harrison is a világ egyik legjelesebb tengerfestője. Az eresz végiben dolgozott, a grófunknak föstött egy kis képet az esőverte szürke tengerröl, cserébe a Bagol András-féle botért.

Tudtuk elöre, hogy remek lesz Harrison dolga, - de az a bot se utolsó!

Készült Somogy megyében, a nagyatádi járásban, Kivadáron, és cselekedte Bagol András maga, miként ez meg vagyon írva a kiteremtettézett somfaágra. Csillagos ólombuzogány a feje s végig hímes az egész, beöntve színes viasszal; csipkézett karikák díszlenek a buzogány alatt s lejebb, szép sorjában, históriás képek és írások következnek. Legelsőbben két lovas magyarok s alattuk a megmagyarázás: „A Magyarok Bejövése 893”. Következik, ágaskodó csikón, egy sisakos magyar s mellette egy kürtös vitéz: „Árpád fejedelem, Lehet vezér". És itt, mielött tovább haladna a nemzeti história illusztrálásában, a müvész helyénvalónak találá fölróni, csupa öreg betükkel, magát a bot történetét is: „BAGOL ANDRÁS MUNKÁJA ÉLJEN A BOT GAZDÁJA”. Ezután következik a négytornyú vár, meg ismét egy lovas ember $s$ az irás: „A szigetvár Ostroma 1566 A HŐS ZRINYI". A szigetvári hőst követi egy lobogós ingujjú csikós, akit nem lehet összetéveszteni mással, mert ott az írás ő róla is: „ISTEN ostora RÓZSA sándor”. Külön keretbe foglalva, megint a bot történetét magyarázza a müvész: „Készült kivadáron, Somogy Megyében, NAGYATÁDI járásban”. És most következik a jelenkor: két huszár, de csak gyalogosan, Kossuth Lajos az egyik, Petőfi Sándor a másik, s köztük egy magyar menyecske, - alattuk, koszorúval körülfonva az írás: TALPRA MAGYAR hí a HAZA PETÖFI szavai Éljen a Szép MAGYAR HAZA 1848 kutya német tönkretette KOSSUTH PETŐFI éljen KIVADÁR."

Malonyay hosszan idézi Somssich szavait Bagol András életútjáról, sőt azt is megtudhatjuk a gróf szavaiból, hogy „Nagy mester az öreg! ... Portrékat is csinál. Egyszer, egy ilyen somfaágra kifaragta a háznépet. Első volt, legfölül, a bátyám, puskával, vadászkalapban s aláírva: A GRÓF. Nyomban alatta, másodiknak A SZAKÁCSNÉ s aztán következett csak a tiszttartó, az ispán, a parádéskocsis és az udvari kovács. De nem csinál esetet az ilyesmiből. A botot beadja a vadásznak, egészséget kívánva grófjának; a konyhában megissza a pohár bort, ami a botért dukál s megyen dolgára."10

Nyilvánvalóan a Malonyay által felvázolt életrajz miatt fogalmazott úgy Mándoki László, hogy „Talán túlzásnak tünhet, hogy kimondottan müveltnek neveztem

9 Malonyay D. 1911: 295

10 Malonyay D. 1911: 296.
Bagolt, a juhászgazdából csősszé öregedett faragót, azt azonban nem naiv történeti ábrázolásai és témái miatt tettem (bár ezek tagadhatatlan olvasottságról tanúskodnak), hanem abszolút stílusérzékkel, következetesen karcolt... betüi miatt. [...] Ilyen kimunkált, enynyire következetesen alkalmazott írásmóddal egyetlen faragónál sem találkozunk." ${ }^{11} \mathrm{~S}$. Kovács Ilona pedig azt emelte ki, hogy „a Bagol-faragványok mérete, formája, szerkezete alig követi a dunántúli pásztorművészetben kialakult hagyományokat”, ${ }^{12}$ sőt: „Bagol kísérletező egyéniség, merészen vállalkozik az újításokra. Ezek közül ki kell emelni az ábrázolásokra való törekvését, ami arra indítja, hogy részben előképek felhasználásával, részben önállóan, a pásztormüvészetben addig ismeretlen kompozíciós megoldásokat alkalmazzon."13 Bagol történeti jeleneteire még Borzsák István is utalt a Zrínyi forrásokról írott tanulmányában. ${ }^{14}$

Az elemzésekben jelenlévő - a Bagol személye és munkái közötti - ellentmondást Szelestey László kutatásai oldották fel. A Baranya megyei botykapeterdi református anyakönyvekben mind Bagol születési, mind halálozási bejegyzését megtalálta, s a „botfaragó pásztor" valódi foglalkozására is fényt derített. Bagol András bognár volt. ${ }^{15}$ Szelestey Bagol által készített sutu-kat is talált, ${ }^{16} \mathrm{~S}$ a helybéli hagyomány szerint a botykai református templom famunkáit is ő csinálta, illetve irányította az építkezést. Bagol leszármazottai azt is tudni vélték, hogy ősük 1848-ban kapitánykényt szolgálta Kossuthot, sőt Turinba is elkísérte. ${ }^{17}$

A hiteles életrajzi adatok és Bagol ismert „pásztorfaragásai” alapján egyértelmű, hogy a botok díszítését csak idős korában kezdte meg. ${ }^{18}$ Ismert munkáinak mindegyike személyhez, vagy egy-egy családhoz köthető ajándék(tárgy). Ezt erősíti Schleicher Verának, egy - a veszprémi múzeumba került bottal kapcsolatos - megjegyzése is: „A múzeum legelső szerzeményei között szerepelt a történelmi tárgyú karcolt botjairól ismert Bagol András egyik alkotása, amelynek kalandos sorsát sejteti, hogy egy kalocsai adományozótól került be gyüjteményünkbe." ${ }^{19}$ A „kalandos sorsot” jól mutatja az is, hogy az Nagyházi Galéria és Aukciósház árverésén 2012-ben szintén feltűnt egy 83 centiméter hosszú Bagol András bot: „faragott fa, színezett karcolt díszítéssel, hazafias jelenetekkel és feliratokkal (Kossuth, Rózsa s. stb.)", Kertész Sándor néprajzi gyűjteményéből. ${ }^{20}$

\footnotetext{
11 Mándoki L. 1978: 265-266.

12 S. Kovács I. 1987: 104.

13 S. Kovács I. 1987: 110

14 Borzsák István: Zrínyi forrásaihoz. (Elkésett megjegyzések Klaniczay Tibor könyvéhez.) Itk 1964. (LXVIII.) 2. szám. 215. 31. jegyzet.

15 Szelestey L. 1987: 1549

16 Szelestey L. 2001: 27

17 Szelestey L. 1987: 1549.

18 S. Kovács, meg a többi felsorolni.

19 Schleicher V. 2006: 301

20 A 2012. november 7-i aukció 337. tételeként került árverésre.
} 


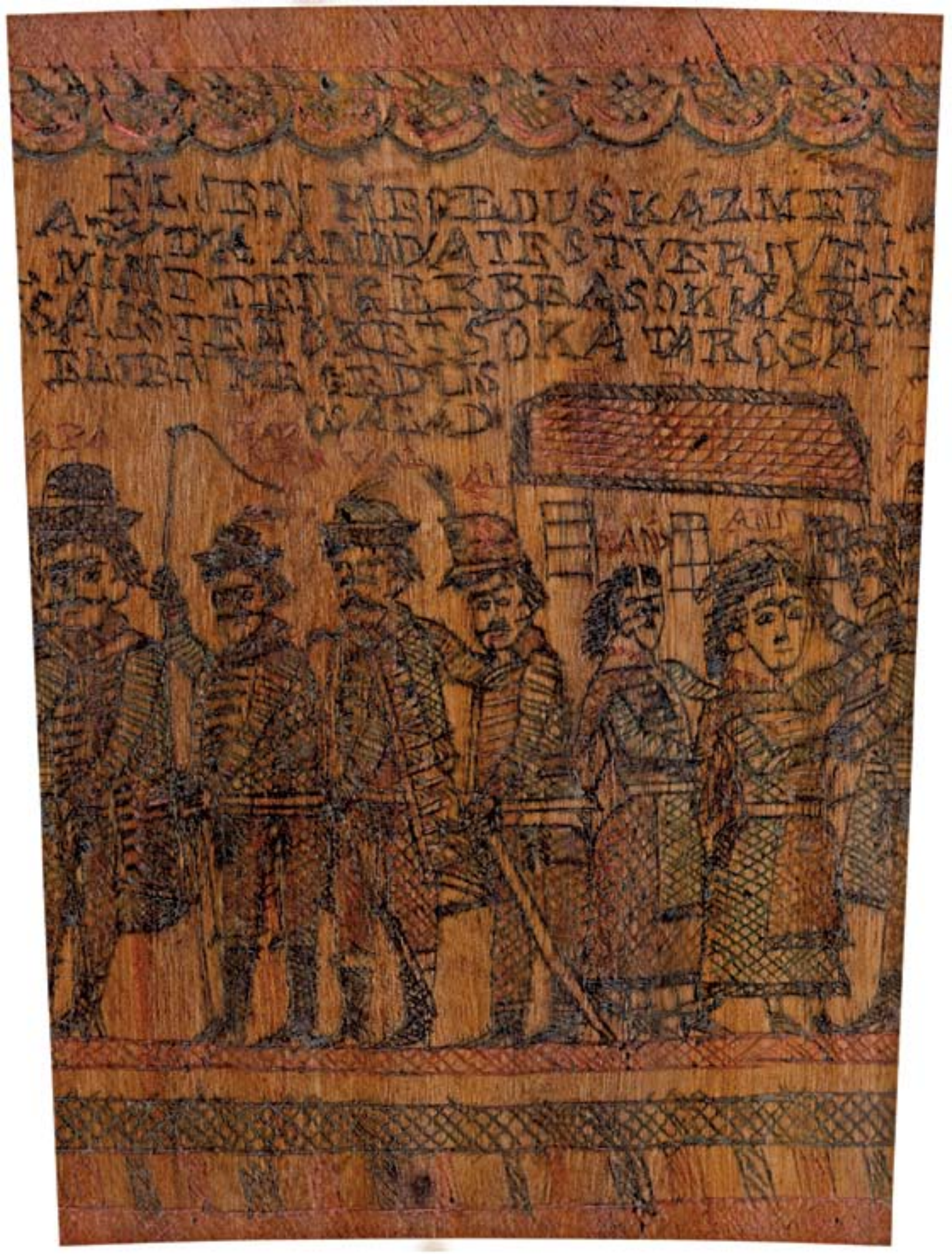

1. ábra: Botjelenet. Hegedűs Kázmér és családja. (Tanai Csaba felvétele) 




2. ábra: Botjelenet. A „kastély”

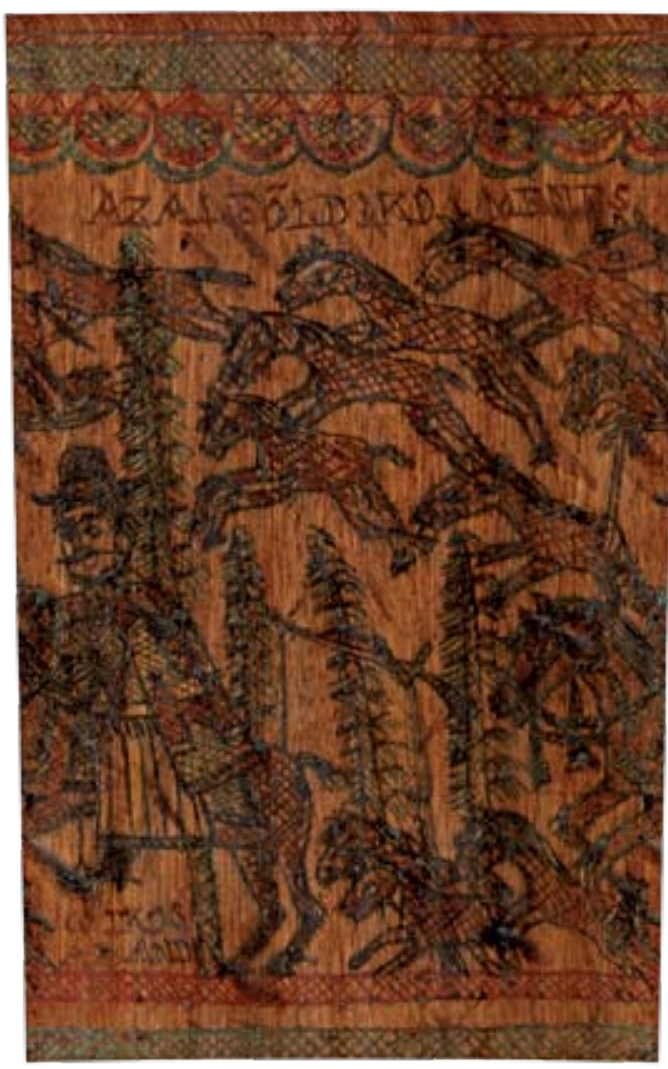

3. ábra: Botjelenet. Az alföldi ménes

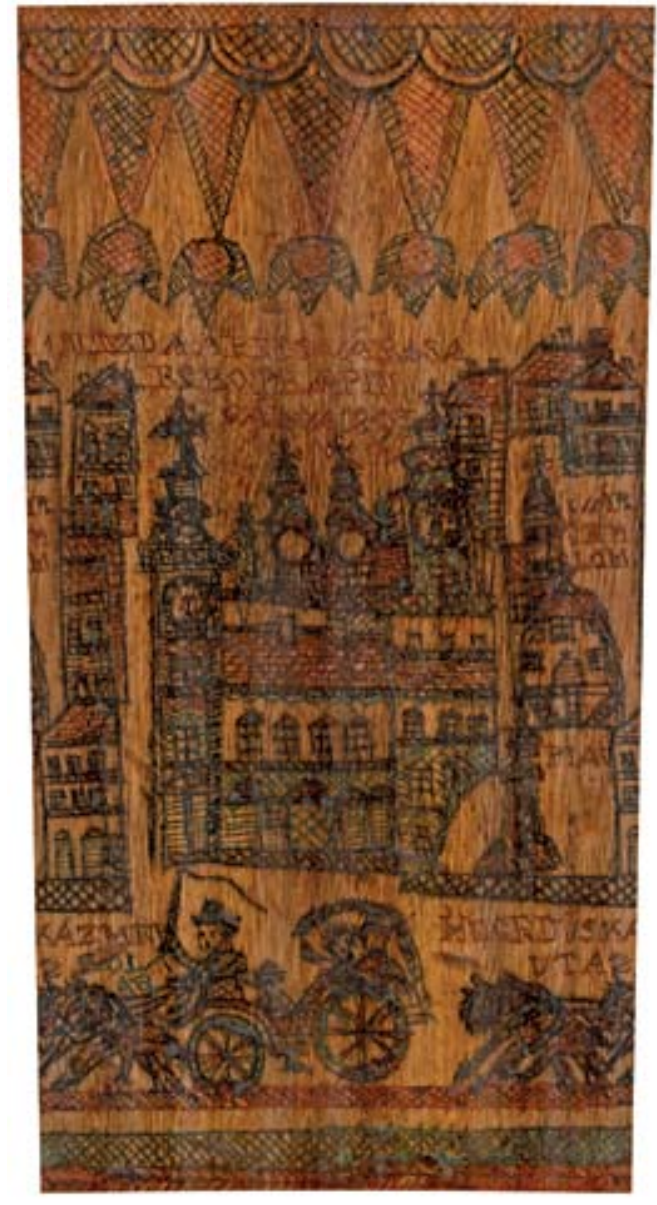

4. ábra: Botjelenet. Pécs városa (Tanai Csaba felvételei) 


\section{A győri múzeum Bagol botja}

Az eddig ismert Bagol munkák sorába illik a győri Xántus János Múzeum néprajzi gyűjteményének darabja is. ${ }^{21} \mathrm{~A}$ szűkszavú leltárkönyvi bejegyzés, ${ }^{22}$ illetve a tárgy leírókartonja szerint a spanyolozott sétabotot Győr-Révfaluban vásárolta özvegy Józsa Vincénétől a múzeum 1973-ban. A bot „gombos végü, ólmozott hegyü. Díszítménye: körkörösen rovott szöveg és körbefutó rajzok. Hegedűs Kázmér tiszteletére faragták. Évszám 1893. Spanyolozott és korommal besimított."

Az egy darab somfából kialakított sétapálca feje, ólmosbotot formáz. A gömböt formázó domborfaragású fej sima, dísztelen tetején vésett körirat olvasható Bagol jellegzetes betűivel:

\section{ÉLJE[N] A HAZA ÉS A KIRÁLY. KE 1877}

A fej alatti képmezőt alul és felül egy-egy gyürü fogja közre, jelezve azt, hogy e rész a bot legfontosabb információit hordozza. Spirálisan körbefutó felirata:

\section{ELJEN HEGEDUS KÁZMÉR \\ ATYTYA ANNYA TESTVERIVEL \\ MINT TENGERBE A SOK HARCSA \\ ISTEN ÖKET SOKÁ TARCSA \\ ÉLJEN HEGEDÜS CSALÁD}

A felirat alatti „csoportkép” középpontjában az APA áll. Vele szemben az ANNYA, karjában egy csecsemővel. Mögötte egy LÁNY. Az apa mögött KÁZMÉR ostorral és karddal. Öt követi két kardos férfi alak feltehetően Kázmér fivérei - VÁL, illetve AL felirattal jelezve.

A választó gyűrü alatti képmező vízszintesen két részre osztott. A felső mezőben két, egy-egy fenyővel elválasztott épület képe látható. Az emeletes, boltíves kapubejáróval és két kéménnyel ábrázolt KAST[ÉLY] mellett mintha ugyanezen épületet látnánk másik nézőpontból.

A képmező alsó részén spirálisan jelenik meg az IRTÁSI RET, az URASÁGI MAJ JOR, illetve a BIRKA $A K O[L]$. Míg az irtási rét és az urasági major „alatt” egy négyökrös szekeret hajtó ostoros figura tünik fel, a birka akol felé KÁZM[ÉR] lovagol az őt gyalogosan követő ostoros alak előtt.

Ez alatt - spanyolozott „sordíszek” között - egy városkép, templommal, házakkal. Felette az írás: NÉZD A A PÉCS VÁROSA EG[Y] BOTRA VAN PINGALVA 1893. A városkép megfelelő helyein a VÁRTEM[P] LOM, illetve PIAC felirat. A kép alján - mintegy a város felé hajtva - négylovas kocsit hajtó KOC[SIS], s jármüben HEGEDÜS KÁZMÉR UTAZ.

A legalsó képmezőben, felirata szerint AZALFÖLDI KD [LÓ?] MÉNES képe. A vágtató lovak közötti föalak bőgatyás kalapos lovas figura. A hozzá tartozó magyarázó szöveg szerint CSIKOS. Az ez alá rótt A BANDI a kép jellegéből adódóan - talán Angyal Bandi lehet.

21 A tárgyról készült rajzot illusztrációként közölte Szelestey L. 2001: 27., illetve szükszavú leírással Tanai P. 2009: 134-135.

22 A botot XJM-N. 73.3.1. számon leltározta be a tárgyat vásárló $\mathrm{V}$. Bíró Ibolya.
A képmezőket négy, arányosan elosztott, egyszerü - piros-,,fehér”- zöld - minta követi. A bot végét ólmozott gyürü védi.

A győri múzeumban őrzött bot tehát tökéletesen illeszkedik abba a „sorozatba” mely Bagol munkásságát jellemzi. Elgondolkoztató ugyanakkor a sétapálcán szereplő két datálás. Míg a boton szereplő 1893-as évszám beleillik abba a képbe, mely szerint Bagol csak a 19. század utolsó évtizedében kezdett faragni, a fejbe vésett 1877 arra utal, hogy már jóval korábban is foglalkozhatott emléktárgyak készítésével.

\section{Bagol András a kortes}

Bagol esetleges korábbi munkáihoz, ábrázolási módjához, a történeti jelenetek, illetve alakok szerepének megvilágításához, s nem utolsósorban a Szelestey által feltárt családi hagyomány „alátámasztásához” jó adalékul szolgál Bagol Andrásnak két - Herman Ottóhoz írott - levele.

A levelek a Magyar Tudományos Akadémia Könyvtárának kézirattárában Ms 250/156-157. szám alatt találhatók. Az 1954-55-ben feldolgozott kéziratok katalógusa szerint 1902-ben íródtak. A levelek tartalmából ugyanakkor egyértelmü, hogy Bagol mindkét levelet 1887 júniusában írta, és küldte el Herman Ottónak. ${ }^{23}$

Az írásokból nem csak az derül ki, hogy Bagol aktívan részt vett a 48-as, illetve Függetlenségi párt választási küzdelmeiben, hanem a Nép Zászlója terjesztője és tudósítójaként közvetlenül használhatta a képes politikai hetilap ábráit - akár faragásainak grafikai előképeként is. Mindkét levélben 48-as katonaként ír magáról, az első írásban pedig felemlíti azt is, hogy „én vagyok az az 48-as ki az Kossúth Lajost Orsovaig kisértem". E levél szerint Bagol egy választási gyűlést követően Herman Ottónak is ajándékozott egy fokost. $^{24}$

A legfigyelemreméltóbb azonban kétségkívül Bagolnak az a versbe szedett programbeszéde, mely tökéletesen rímel a botokon megjelenő történetszemléletével, az ott kiemelt alakokkal és eseményekkel. ${ }^{25}$
23 A datálás pontosítását a levelekhez füzött jegyzetekben fejtem ki bővebben.

24 E tény tágíthatja Bagol „botfaragó” munkásságának eddig ismert időhatárait!

25 A leveleket szó szerint közöljük. A könnyebb olvashatóság kedvéért ugyanakkor - a Bagol által mindig egybeírt névelőket elválasztottuk az azokat követő szavaktól. Az értelemzavaró tollhibákat [ ] között egészítettük ki. Az olvashatatlan részeket [?] jeleztük. 


\section{Nagyságos Herman Ottó Képviselő Kegyelmes Uram!}

Ha kegyelmet találtam előtte tehát ezen verseket adja által a nép zászlójába és a bükösdi beszédemet nyomassa ki az leg közelebbi ujságba és amint Sziget várat a rózsa vendég fogadóba beszédet tartot én anak eredményéből beszéltem én vagyok az az 48tzas ki az Kossúth Lajost Orsovaig kisértem ${ }^{26}$ és két jelasits Huszárt és 7 gyalog rátzokat mint bakakat el fogtam ahol az Turányi erdőben 2.500 ember közt kapitány voltam töbed magammal és azokat kormánynyoztam, több polgár fiú nem támat se Baranyaba sem Somogyba, mert nékem kitüzetett az akasztó fa. De el ugrotam mint család és két kis fiúnak atya ${ }^{27}$ és menedékembe menekülésel éltem kenyerem 2 és fél évig - ahol a meg szabadulásom után Ő felsegetűl nyertem Szabad lábám meg vedéssét igen sokból álana az egész történetet leirni mert egypár árkúsra nem térne.

Csak anyit írok hogy az Szerkesztősség ki adó hivatalának már elvolt küldve irásba hogy énis akarok a nep zászlónak tagja és gyujtöje lenni mert aki 48ba 2.500 embert kormányzot mint fel kelt népet egy azon Szavamra igen sokan fogunk meg szaporonni a nep zaszloja meg rendelésébe, anál inkább ne sajnálják a beszédem és a választási Dalokat egyik hassáp közt kinyomatni én ha megkapóm a nép zászlót rögtön minden héten való történetet mely nálunk az alvideken történt fel fogom küldeni az nép zászló ki adó hivatalához Buda pest IV. Ketskeméti utza 6dik szammához. ${ }^{28}$

Ezek után Nagyságos Herman Ottó Urat az Isten soká éltesse, azón hazánk Ditső fia Kossúth Lajos meg látogatóját melyet az előbi lapból ólvastam az Ötsém Bagol Janós út mutatássával melynek sziv erejéből fógalmaztam irásaimat kivánom a nép zászló ki adó hivatalnokokat is halálig tiszteletbe és betsületbe tartani és uj gyüjtőimet is meg tisztelni. Eljen soká jó Egésségbe mint anyi - Szolgája Bagol András Botykai lakós ki Sziget várat meg köszöntöte és az emlék kis fokóst 2 forintot ada ${ }^{29}$

\section{u. p. Nagypetend}

Pünkösd más napján tartott Beszéde Bagól András köz polgárnak ahól 250 ember jelenvólt az értekezleten a Bükösdi kastélba Jeszenszki Ferentz kép vise-

26 A családi hagyomány szerint Bagol, mint egyik leghübb embere Turinba is elkísérte Kossuthot. Szelestey L. 1987: 1549.

27 Szelestey L. 1987. szerint Bagolnak négy gyermeke volt: Zsófia, József, Károly és Lajos. (Egy János nevű gyermeke ötnapos korában meghalt.) A levél alapján 1849-ben Bagolnak már két élő fiúgyermeke lehetett.

28 A Nép Zászlója című képes politikai hetilap 1868 elején (január 4.), a demokrata körök alakulásával egyidőben látott először napvilágot. „Lapvezére” Madarász József képviselő, a pesti Demokrata Kör jegyzője lett. A levélrészlet szerint Bagol - mint „tudósító” - már korábban is kapcsolatban volt az lappal.

29 Ezek szerint Bagol már 1887-ben is készített faragványokat. Ez a Hermann Ottónak ajándékozott fokos lappang, esetleg azonos lehet azzal a datálatlan darabbal, melyet Endrei közölt, esetleg a Janus Pannonius Múzeum - szintén datálatlan - JPM 52.795.1 leltári számú díszfokosával. lőnk ${ }^{30}$ [?] beszédébe ${ }^{31}$

Tisztelt polgár társaim és Úraim

Imé ez azon Ditsőséges nap, melynek Súgára az egész magyar hónunkba behat. Nézetem szerént Ugy veszem észre hogy önök kebele ujra ismét ég, azon pragmón melyet Kossúth nagy hazánk fia meg szerzet a számúnkra Éljen Kossúth!!! éjenzés

\section{Tisztelt polgártársaim haljúnk haljúnk}

Én meg vagyok győződve azon hogy talánd nints oly magyar ember kinek szive ne fájna azon hogy a meg szerzet magyar hazánkat, mely kard és vér fojásával alakitatot meg - meg szálta egy oly féreg melynek sem [?] sem fáratságába került volna amidőn hoszan tartó küzdés után a hős Árpád panoniát magyar országnak nevezte - elöször is a perzsiai királyjal kelet meg ütközni, a hol az ő kevés katonai látván hogy temérdek nép ál pezsi király seregébe meg félemlenének, De Árpád bátorita vitézeit ily szóva[l] Emlékezetek vitézim ara hogy Ősseink Átila vezérlésse alat, azt fogaták hogy kardal és vérel Szereznek jobb hazát - ne féljetek úgy nézétek a perzsabéliek sokságát mint a legyek sokaságát mert egy köjkes Szarvas sok fene órószlánt meg zargat az erdőben és a sikságba - meg fujata Árpád a tárogató sipjait és órószlány módon meg rohanák perzsiakat és anyira küzdenek a lelkesités után hogy meg verék azokat anyira hogy a perzsiai királyt el fogák, és a had meg csendessede - meg számlálá Árpád a katonáit, és azok háláit, minden egyes katonáira azokból 20 eszerit nevezte a hős vezér Árpád őket huszároknak, mely máiglan is él, e szó - igy tegyünk miis, és azon utána támmat mássodik Árpád, ki még életbe van ki anak nyomdokát követe Éljen Kossúth Lajos hazánk ditső fija - nagy zaj sok éljenzés éljen Kossúth Lajos

\section{Tiszte[l]t polgár társaim}

Látván a hős vezér hogy az első indulása Szerentsés, meg indúla Etelközböl erdéjen át, és oly véres ütközetet tart vala - hogy legelőször Úngh várt vete be, és meg támata seregeit enek főparancsnokát Laboitzát fel akasztatta, a totok vezérjeit és fő vezérét Zobór nevü a nyitra leg magasab hegyén fel akaszttata, és a totokkat Kárppád hegye alá szorita, máiglan is

30 ASturm-féle OrszággyűlésiAlmanach szerint: „Jeszenszky Ferenc, Baranya megye, Szentlörinc kerület. 1846-ban a baranyamegyei Bükkösdön született; fia Jeszenszky Ferencnek, Baranyamegye volt alispánjának. A jogi és államtudományokat a pozsonyi akadémián hallgatta. Tanulmányai végeztével Baranyamegye tiszteletbeli aljegyzőjévé választatott. 1868-ban önként belépett a honvédség kötelékébe; két évi tényleges szolgálat után hadnagyi ranggal szabadságolt állományba lépett és bükkösdi jószágára vonult. Mint baranyamegyei nagybirtokos és bizottsági tag élénken részt vett a megyei közgyülések tárgyalásaiban. 1881-ben a szentlörinci kerület nagy többséggel képviselővé választotta és e kerületet 1901-ig képviselte. Az 1901/6. évi országgyülésen nem volt a parlamentnek tagja, 1905-ben, valamint 1906-ban azonban újra megválasztatott. A függeltenségi és 48-as párt híve."

31 1887-ben Pünkösd május 29-én volt. 
ottan van lakhejek - akor az Ő Ditsőséges győzedelme után panoniát nevezte magyar országnak 893 évben igy vegyék mast beszédemet atyámfiai hogy meg magyarázom, a mostani korszak ügyeit

Haljunk haljunk

Jézus amidőn emberi testben a földön járt meghatta a tanitványinak és a sokasságnak, hogy én meg halok De majd jönek én utánam ánti Krisztusok akik a népel el hitetik hogy ők a bizonyosak, akik bárány bőrbe öltöznek és farkas nyilai belül ragadozva álanak - és az ő cifra szavaikal eget menyet $s$ földet igérő noha semivel nem biró ergonimás beszédel rúkolnak ki - De nekik ne hidjetek nékik nints töbé remény magyar ország számára a felséges fejedelem sem gondól velünk minden igasságos törvény el hagy benünket, készülünk a pusztasságra, tudatni kel a minisztériumot, kivált Tisza Kálmányt ki izó vassat vesz kezébe, nem akarja é azt vízbe mártani hanem haj[ó] törésnek menek eleibe miként órvósólhatnának enyi nyomórt egy emberhez hasonlitom őket, ki az szél elen indúl, és nem nyerheti visza az ő lélegzetét.

\section{Nagyon tisztelt polgárok és képviselő Urak és töbi}

Tekintsetek csak az Erdő mélyében ahol őzek és a szarvasók és más nemü álatok tanyáznak nem Uralkodik azok közt bizalom, hanem mindenki esméri az őnemét, valamint az ökör az ő urát, Szamár az ő urának jászlát - De Tisza nem esméri a földmívelő pólgárt - Nagy zaj és tapsolás éljen Bagó And[rás]

$$
\text { Tisztelt polgárok hajúnk }
$$

Ha az ég rajtunk könyörül és ezen fügetlenség párt többségre verődik figyelmeztesse a miniszteriumot hogy azon terhes adosságát mielöbb törlesze le és a magyar embert a maga jogába szabadon rendelkeztesse mert mi bérlők vagyunk és selérek, mert gonosz és istentelen emberek árasztoták el magyar ország tartományát véren szerzet földjét, fel emésztik verítéki gyümöltsét, és az véren szerzet földjét vetessék el jó magal a konkolyt hányák ki a buzábol igy terem földünk jó gyümöltsöt, melyre minden ajkú nép azt kiáltja éljen a haza, Éljen a király - Éljen Kossúth Lajos ezen nagy hazánkfia és mind ezek követei ámen.

Nagy zörenés és sok éljenzés háromszor emelték fel Jeszenszkit a Kossúth pragmába és éllelék

Bagol András

Követ választásra és nép kedvére készitet versek a szent lörintzi kerületbe

Árpád hőssünk hü veze[r]ünk meg hala

De anak a sarjadéka ki hajta

Kossúth let anak a fénylő csillaga

ne fély magyar meg kézbe van a haza
Ditső Árpád perzsiák meg verője Ezt a hazát kardal vérel szerzette Katonáit oly szépen bátoritá egy egy vitézt huszra is ki számítá

Akór volt az első szó, hogy huszárok meg szólalt a tábori síp nótájok Etel közbül erdéjen át sebessen Úngh várt veték először be ügyessen

Az után termet egy csinos eper fa melynek ága fel világra ki hatta levelei már sárgulnak és halnak de gyökeri még erőssen álanak

Ezer nyóltz száz negyven nyóltzba virágzót Rögtön utána erőssen szagozót Kóssúth Lajos vólt enek a kertésze De Görgei szép virágát letépte

Indúlnak a négyes ökör fogatok Minden felül magyar ászlók lobogtak Bömbölt a szél világosnál jött a hír Ott ássatot a magyarnak egy mély sír

Örült ezen a kormány párt és tagja De nem alút ki még magyar lámpája Kisüt még ránk Kossúth Lajos csillaga Ezen öszve vesz a kormány párt tagja

Ezer nyóltz száz nyóltzvan hétbe kiderül Még a kormány párt hajoja elmerül A mi hajónk evezen is elöre Had kúlogjon a kormánypárt szekere ${ }^{32}$

Tisza Kálmány hegedüt vesz kezére Egy bús nótát húz társinak zenére Szilágyi ${ }^{33}$ és Sákovits a nép közt jár [?] ${ }^{34}$ A töbi társ köszt komoljan tántzot jár

Szent lörintzi kerületünk szépen ál Csak Ladányi néha köztünk kujtorgál ${ }^{35}$ Úgy jár mint az Őszi Rózsa a dér[r]el Visza lép Somogyba nagy vesztességel

Éljen Jeszenszki s független pártjai Ezt kivánja a nemzetnek jövői Meg szavazunk fel kiáltúnk s éltetünk Jeszenszki a haza fias követünk
32 Egyértelmü utalás a választás, és egyben a levél (vers) keletkezésének idejére.

33 Szilágyi Dezső 1887-ben, a siklósi kerületben kisebbségben maradt, Pozsony I. választási kerületének képviselője lett.

34 Olvashatatlan, kihúzott, javított rész

35 Ladányi György 1883-tól az Istóczy-féle antiszemita párt támogatója. 1887-ben a szentlörinci kerületben a Függetlenségi és 48-as antiszemita párt jelöltje volt. 
Éljen Rúdólf mint hű tron örökös ${ }^{36}$

Magyar nemzet ő iránta hüségös

Légyen szabad német tót és a magyar

Mert jól tudjuk hogy a magyarnak jót akar

Kiáltsd magyar éljen hazánk királyunk

Minden hartzon hiven melete áljunk

Csak hủ légyen igasságos mint Mátyás

Panasz rola ne légyen mint Tisza s más

Éljen Kossúth Éljen anak két fia ${ }^{37}$

Légyen magyar országunknak lakója

Had temessünk it el hona sirjába

Bús könyeket hulassunk sír halmára

Bagol András

Bagol második levelének már „hordozó anyaga” is jól mutatja az írás keletkezési idejét. $A$ beszámoló egy - „Irányi Dániel, mint az országos 48-as függetlenségi párt végrehajtó bizottsága elnökének sürgönye" címü - 1887. június 16-ára, a szentlőrinci választásra nyomtatott röplapjának hátoldalára került. A levél pedig tartalma szerint egyértelműen a június $17-i$ választás lefolyásáról, eredményéről számol be.

\section{Nagyságos Herman Óttó Órszágos Kepviselő Urnak}

Alúl irót 48ass Kóssúth Elvein áló maiglan is ide

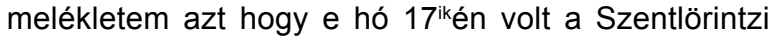
járássunk képviselő választás napja ki tűzve ${ }^{38}$ ahol Ladányi György Jeszenszki Ferentz Úr elen pártja vala. De minek utana nagy Esőzés miat több hejjekről kesőbb jötek a választok ki jelölt hejre, De Botyka Betsefa, kis peterd Szt. Örzsébet ${ }^{39}$ Nagypeterd

36 Habsburg Rudolf trónörökös 1889. január 30-án Mayerlingben meghalt.

37 Kossuth Lajos 1894-ben elhunyt, fia Kossuth Ferenc pedig 1895töl már képviselő volt.

38 A dualizmus korában tartott választások közül csak az 1887-ik éviben volt lehetséges „e hó” 17-én választásra, mivel ebben az évben a választási időszak június 17 -e és 26-a között volt. Az 1892. évi január 29 - február 3 , az 1896-os, október 29 - november 4 , az 1901. évi pedig október 2 - október 9 közé esett.

39 Ma Nyugotszenterzsébet.
Büdösfa Bánfa Dentsházai választó szavazó polgárok nagy számal öszve jötünk egy rész Botykába inét a töbi fent írt kössegekkel Nagypeterden ahól a sok kotsik és a nép tömegesége 1 kiló méter hoszat tartot a menetrend Csak kotsi több volt 100nál aki jön 5. 6. ember szavazo ült az uton mikor az Eső el ált jöt minden felül a nagy tömeg anyira meg szaporodót Jeszenszki párt szavazoi hogy anyit én még nem tudók vólt a sok ejenezés a [?] átal Ladányi [?] népeihez. En meg olvastam Jeszenszki párt ászlajait találtam a hej színen 418dikat a Ladányi nepeből hozám jöt egy kórtes, ki alitolag monta hogy 416 szavazoja van mind öszve akor én át kiáltotam, több ászló[n]k van nékünk mint tik szavazok egy fél óra után jöt a hir Ladányitul fel mondat a szavazasról a hol már az ő nepeből 140 szavazók amiekből az Jeszenszkire. 638 vólt ekor berekesztetet így a nép öszve tért - és Nádassi Kálmány bizotsági tag ki fel kiáltota hogy meg szünt a szavazás egy hangúlag Jeszenszki let a követ ezt kérem a leg közelebi ujságba tetesse ki

\section{Szolgaja Bagol András} 48cas nagy kórtes

\section{Irodalom}

GYöRFFY I. 1983: Adatok Bagol András botfaragó munkásságához. In: Ethnographia XCIV (1983) 423-431

Malonyal D. 1911: A magyar nép művészete. III. A Balaton melléke. Budapest 1911.

MÁndokı L. 1978: Bagol András faragványai Pécsett. - In: Somogyi Múzeumok Közleményei III. 263-270

S. KovÁcs I. 1987: Bagol András faragópásztor. - In: Ethnographia XCVIII (1987) 101-112

S. KovÁcs I. 2001: Pásztorművészet. In: Kapitány Orsolya-Imrő Judit (szerk.): Somogy megye népmúvészete. Kaposvár, 2001. 329372
SCHLEICHER V. 2006: „Kakukktojás” tárgyak a Laczkó Dezső múzeum néprajzi gyüjteményében. - In: A Veszprém Megyei Múzeumok Közleményei 24. 297-311

Szelestey L. 1987: Ki volt Bagol András? - In: Élet és Tudomány 1987. 12. $04.1548-1549$

Szelestey L. 2010: Bagol András élete és munkássága. - In: Dobogó IX. évfolyam 6. szám 26-27

TANAI P. 2009: Néprajzi gyűjtemény. In: Székely Zoltán (szerk.): Válogatás a javából. A 150 éves győri Xántus János Megyei Múzeum gyűjteményei. Győr 2009. 110-135 